\title{
Genetic and Molecular Regulation Mechanisms in the Formation and Development of Vegetable Fruit Shape
}

\author{
Chen Wang ${ }^{1,2,3,{ }^{\dagger}}$, Jiajian Cao ${ }^{1,2,3,{ }^{\dagger}}$, Ning Hao ${ }^{4}$ and Tao $\mathrm{Wu}^{1,2,3, *}$ \\ 1 College of Horticulture, Hunan Agricultural University, 1 Nong Da Road, Changsha 410128, China; \\ wangchen0620@foxmail.com (C.W.); caojiajian@hunau.edu.cn (J.C.) \\ 2 Engineering Research Center for Horticultural Crop Germplasm Creation and New Variety Breeding, \\ Ministry of Education, 1 Nong Da Road, Changsha 410128, China \\ 3 Key Laboratory for Vegetable Biology of Hunan Province, 1 Nong Da Road, Changsha 410128, China \\ 4 The Laboratory of Plant Nutrition and Fertilizers, Graduate School of Agricultural and Life Sciences, \\ The University of Tokyo, Tokyo 113-8657, Japan; haoning0925@hotmail.com \\ * Correspondence: wutao@hunau.edu.cn \\ + These authors contributed equally to this work.
}

check for updates

Citation: Wang, C.; Cao, J.; Hao, N.; $\mathrm{Wu}, \mathrm{T}$. Genetic and Molecular Regulation Mechanisms in the Formation and Development of Vegetable Fruit Shape. Appl. Sci. 2022, 12, 1514. https://doi.org/10.3390/ app12031514

Academic Editor: Luca Mazzoni

Received: 10 November 2021

Accepted: 25 January 2022

Published: 30 January 2022

Publisher's Note: MDPI stays neutral with regard to jurisdictional claims in published maps and institutional affiliations.

Copyright: (c) 2022 by the authors. Licensee MDPI, Basel, Switzerland. This article is an open access article distributed under the terms and conditions of the Creative Commons Attribution (CC BY) license (https:/ / creativecommons.org/licenses/by/ $4.0 /)$.

\begin{abstract}
Vegetable crops have a long history of cultivation worldwide and rich germplasm resources. With its continuous development and progress, molecular biology technology has been applied to various fields of vegetable crop research. Fruit is an important organ in vegetable crops, and fruit shape can affect the yield and commercialization of vegetables. In nature, fruits show differences in size and shape. Based on fruit shape diversity, the growth direction and coordination mechanism of fruits remain unclear. In this review, we discuss the latest research on fruit shape. In addition, we compare the current theories on the molecular mechanisms that regulate fruit growth, size, and shape in different vegetable families.
\end{abstract}

Keywords: fruit growth and development; fruit shape; hormonal and genetic interactions; cell division

\section{Introduction}

The diversity of plant fruit morphology is related to the adaptation to environmental changes during evolution. In the case of vegetables, fruits can be divided into dry dehiscent and fleshy fruits [1]. Dry dehiscent fruits are mainly distributed in Cruciferae crops, whereas fleshy fruits are found in Solanaceae, Cucurbitaceae, and Asteraceae. Predictive reports about the evolution of angiosperms indicate that fleshy fruits begin with silique, and their genetic regulation network is highly conserved [1,2]. Similar to the different kinds of fruits, the edible parts are also diverse. In the case of Cruciferae, most people feed on edible leaves, whereas in Asteraceae, mainly roots or tubers are consumed. However, in certain vegetable crops, the fruit is not only used for consumption but also cultivated and used to spread seeds. Solanaceae and Cucurbitaceae fruits are large, delicious, and rich in nutritional value. Therefore, the edible part in these families is often the fruit part that can carry seeds. Fruits have evolved into different shapes to adapt to various forms of seed dispersal. In addition, human domestication has promoted the formation of fruit diversity, which has led to a variety of fruit shapes among the same species [3-5] (Figure 1). Humans select large fruits in fleshy fruit domestication. The fruit length (FL) of domesticated squash deviated from the original round shape, resulting in flat scallop and long crookneck shapes [6]. Through elongation and flattening, fruits change shape from having similar lengths and widths to dimensions greater or less than 1:1 [7]. Although fruit morphology presents a diversified distribution, the related mechanism research has not been fully explored. This review mainly summarizes the developmental process of fruit shape in vegetables. Understanding the diversity of vegetable fruit morphology and their molecular regulatory mechanism will provide a basis for molecular biology research on vegetable fruit shape. 


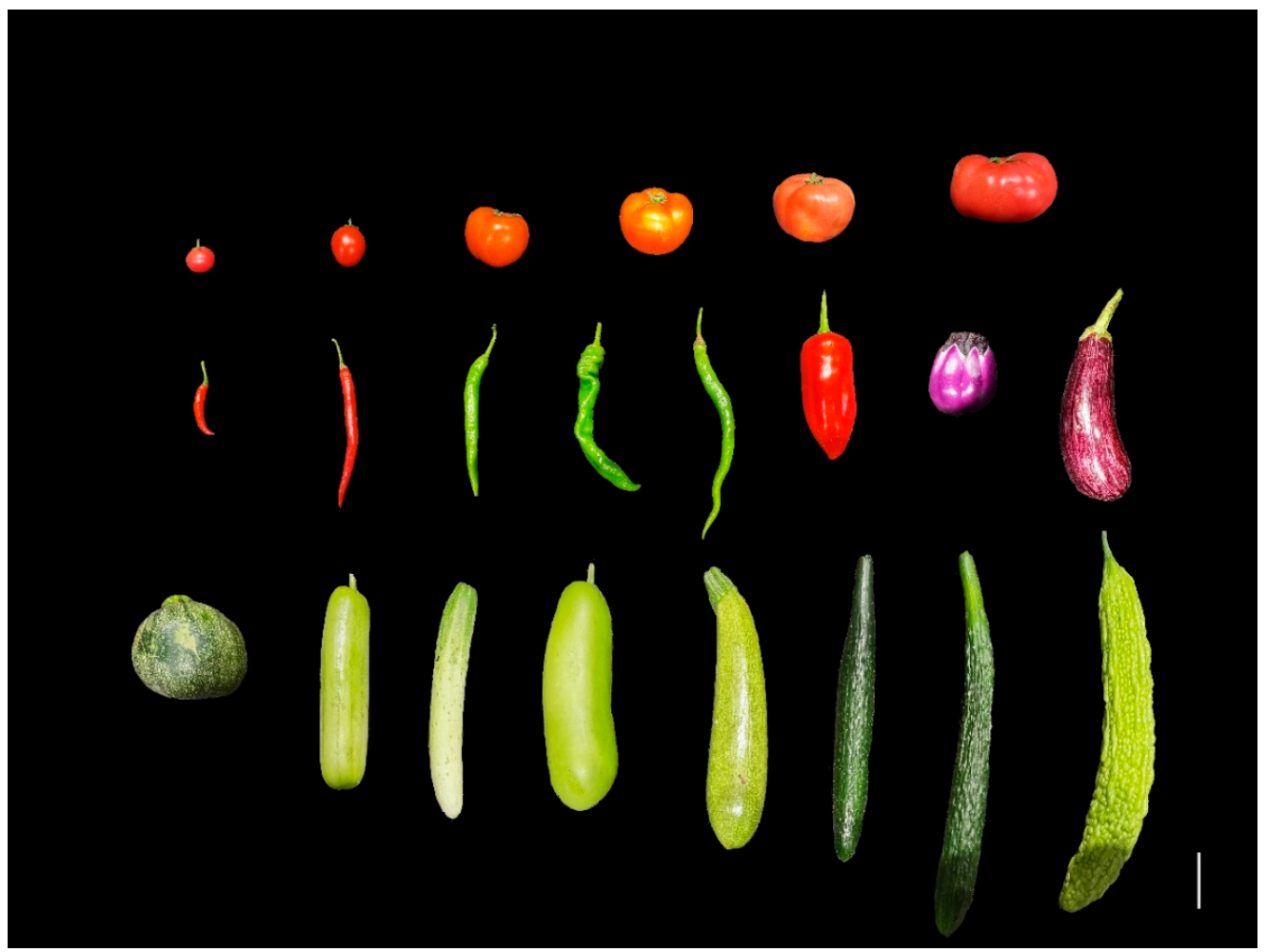

Figure 1. Diverse variations in fruit morphology of the Solanaceae and Cucurbitaceae families. Row one: Solanaceae; Row two: Solanaceae; Row three: Cucurbitaceae. Bar $=5 \mathrm{~cm}$.

\section{Cell Development Process of Vegetable Fruit Formation}

Cell development is closely related to fruit shape. In general, cell development mainly occurs due to changes in internal cell shape and fruit structure, which affect the development of fruit shape in a particular direction. The direction, period of cell division, and expansion can affect the fruit shape and ovary size, which are related to the rate of cell division $[8,9]$.

In vegetable crops, such as tomatoes, numerous genes (OVATE, SUN, FAS (FASCIATED), and LOCULE NUMBER (LC)) affect the fruit shape and size. In cucurbits, the above gene family members exhibit different distributions on seven chromosomes such as melons and cucumbers $[5,10]$. In pumpkins (Cucurbita pepo), the increase in cell number can lead to a large fruit size [11]. Two cucumber varieties, Gy14 and CL9930, have different fruit shapes. During fruit growth, the division and expansion of fruit cells lead to different cell numbers and shapes in the transverse and longitudinal sections [12]. In addition to cell development, the cell cavity between cells plays a decisive role in fruit shape [13]. The changes in pumpkin fruit shape are caused by cell proliferation in the early stages and cell expansion in the later stages $[14,15]$. In addition, in cucumbers, melons, and other horticultural crops, the timing and duration of cell expansion and division may cause the fruit size difference [16-28].

Fruit development can be roughly divided into four stages [29]. The first stage involves the formation of floral organs and the production of mature flowers. This process lasts for about 14-21 days and determines the identity, number, and shape of floral organs. The second stage, which lasts for two weeks, is the intensive cell division period, and it starts at the beginning of anthesis and ends after fertilization. The third stage is the cell expansion period, during which cells expand more than 20-fold [30,31]; this starts from the end of the second stage and continues until the first week before the mature period begins. The fourth stage involves fruit maturity. At this stage, the size and shape of the fruit show no change, but the aroma, color, texture, and internal biochemical components transform rapidly $[32,33]$. The proliferation and expansion stages of cells are generally considered the 
main stages that affect the growth of floral organs [34,35]. In floral organs, the duration and rate of cell proliferation determine the number of cells, whereas cell expansion determines the final size [36].

\section{Genetic and Molecular Regulation Mechanisms of Vegetable Fruit Shape}

In the past ten years, in order to classify the fruit shape of a tomato accurately and effectively, Brewer et al. have developed a software program called Tomato Analyzer [37]. They analyzed eight species of tomatoes as follows: round, obovoid, long, heart, oxheart, rectangular, flat, and ellipsoid [38]. Cucumber, melon, watermelon, and other cucurbit crops have a relatively single fruit shape change, such as cylindrical, oval, or round [39]. The fruit morphogenesis and development are influenced by the combination of internal and external factors, which ultimately dictate the fruit shape. The internal factors include regulatory genes and protein interactions. On this basis, we classify and summarize different fruit shapes and study the specific regulation mechanism of fruit shape formation.

\subsection{Carpel Number (CN)}

The $\mathrm{CN}$ is one of the most important fruit traits among vegetables, it can affect the fruit shape and size. In nature, fruits generally have two or more carpels. These differences are related to domestication and mutation. In addition, further research shows that common regulatory factors can play a role in the CN of fruits. In Arabidopsis, CLAVATA (CLV) and WUSCHEL (WUS) can generate negative feedback in regulating the size of the meristem and the number of floral organs [40,41]. Mutations in the CLV family genes lead to an increased number of undifferentiated cells in the central region, causing the expansion of the meristem [42]. Large floral meristems result in increased CN and fruit width [43-45]. Moreover, the function of the CLV-WUS pathway is conserved in higher plants [46] and regulates the number of fruit carpels in cucurbitaceous, solanaceous, and cruciferous plants [47-50]. In cucumbers, two transcription factors (TFs), namely, FRUITFULL-like MADS-box gene $\left(\mathrm{CsFUL1}^{A}\right)$, and CsARF14, can regulate the CsWUS-CsCLV3 pathway and work together to participate in the regulation mechanism of the cucumber CN [47]. In tomatoes, the loss-of-function mutation SlCLV3 leads to a large fruit with an increased number of locules [48,49], and the up-regulation WOX1 TF family members of SIWUS can increase the $\mathrm{CN}$ and affect fruit shape [51,52]. In tomatoes, $L C$ is encoded by WUS, whereas FAS is encoded by CLV3; $l c$ and fas can lead to a high locule number [53]. In addition, the transcriptional regulation of small and long non-coding RNAs can regulate fruit shape. MicroRNA 156 (MIR156) overexpression alters the locule number of the tomato fruit [54]. In rapeseed, the interruption of CLV1 results in a trilocular phenotype [50] (Table 1). In addition, the $Y A B B Y$ family is also a plant-specific TF, and several of its members can increase the number of locules and flat fruit shape in tomatoes $[38,55]$.

\section{2. $F L$}

In vegetable crops, the FL is an important phenotypic trait. Numerous factors affect the FL (Table 1). With FL as a quantitative trait, people have discovered several related loci by Quantitative trait locis (QTLs) mapping, whereas numerous candidate genes related to FL have been discovered (FS3.2, FS3.3, fl3.2, $m f l 3.2, f l 7.1, f l 4.1$, and $f s 10.1$ ) [56-59]. In addition to the loci, researchers identified a series of genes and regulatory pathways that are involved in vegetable FL. In cucumbers, short fruit (sf1) and CsFUL1 can change the FL [60,61]. Wang et al. identified the $s f 3$ mutant in cucumbers and observed a homolog of the KTN1 (CsKTN1) candidate gene, which encodes a katanin p60 subunit, is associated with the regulation of FL [62].

In tomatoes, SUN, Ovate family protien (OFP), and Tonneau1-recruiting motif (TRM) regulatory factors can affect the FL individually or together. In 2002, Liu et al. identified a pear-shaped fruit regulatory gene OVATE in tomato [63]. OFPs with a conserved OVATE domain play an important role in regulating fruit size. OFPs are plant-specific TFs. Two members of the family, namely, OVATE and SLOFP20, have been extensively studied in 
vegetables. The OVATE gene can cause the pear-shaped fruit, and SIOFP20 can affect the development of floral organs and pollen tubes by modulating brassinosteroid (BL) and gibberellin (GA) signaling in tomatoes [64]. In Arabidopsis, the overexpression of AtOFP1 results in a reduced length of floral organ phenotype, which is similar to OVATE and SlOFP20 overexpression tomato plants $[63,65]$. In the ovate mutant, the cell division pattern of the fruit proximal part changes, the numbers of cells in the proximal and distal directions increase, whereas the number of cells in the middle direction decrease [66]. Additionally, the locus suppressors of OVATE 1 (SOV1) can enhance the OVATE mutation [67]. In addition, the overexpression of Arabidopsis OFP homologous genes (AtOFP13, AtOFP15, AtOFP16, and AtOFP18) results in a reduced length of siliques [68-70], these genes are also involved in the regulation of fruit shape, indicating that this family may also control the organ shape in other plants [71]. At present, the molecular mechanism of OVATE is unclear, but it has been shown to interact with microtubule-related proteins, such as TRM [72]. OVATE and SIOFP20 interact with the TRM M8 motif through the OFP domain, and the co-expressions of OVATE or SIOFP20 with SITRM3/4 causes the re-localization of OFPs and TRMs from microtubules to the cytoplasm, suggesting that the OFP-TRM protein complex plays a role in cell division and organ growth through a dynamic balance between cytoplasmic and microtubular localizations [73,74]. In other vegetables, the down-regulation of the CaOvate gene leads to the oblong fruit shape of peppers [75], which indicates that the OFP family is relatively conserved in relation to fruit size [65].

SUN encodes a protein of the IQ 67 domain (IQD) family, which has a conserved IQD and is involved in the binding of Calmodulin (CaM) [38,76]. SUN is reported to control the FL and shape in tomatoes, melons, and cucumbers [5,76-79]. The IQD is a conserved region of 67 amino acids and contains up to three regularly spaced IQ motifs that promote CaM binding in the presence of $\mathrm{Ca}^{2+}$ [80-82]. In tomatoes, the shape change mediated by SUN is consistent with the cell division stage after 7-10 days of pollination [83], which increases cell elongation and division along the proximo-distal axis [84] and can be used to determine the fruit morphology by regulating the microtubule dynamics. Lazzaro et al. [65] proposed a model to describe the regulation of the tomato fruit shape by SUN, OFP, and TRM interaction, in association with microtubule development. Rho proteins of plants (ROPs) are plant-specific Rho GTPases [85], and one of their functions is to organize microtubules and act on the cytoskeleton to determine a cell's final shape [65]. Several IQD proteins can guide the formation of ROP domains to regulate the cytoskeletal architecture in the plasma membrane [65]. In the interaction network, the up-regulation of TRMs and SUNs or down-regulation of OFPS can lengthen the tomato fruit [65]. Studies further show that OFPs, TRMs, and SUN/IQD can affect the activity of microtubules and fruit shape. In addition, in different species, SUN family proteins play a role in regulating FL. In cucurbitaceous crops, CsGy1G026840.1 and Csa1G575000, CmSUN-14, and Cla011257 belong to the SUN family and can regulate the FL $[5,39,65,78,86]$. Further research revealed

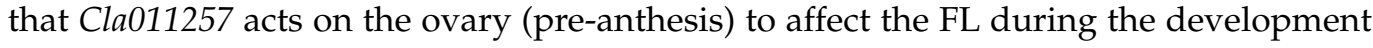
period [87].

The MADS-box family TFs are closely related to plant development and play an important role in flower and fruit development [88]. As an important TF member of the MADS-box family, FUL affects FL in different plants. In tomatoes, MBP7/FUL2 can regulate fruit shape through cell division and expansion. When the FUL genes encoding MADS-box are knocked out in different species, the fruits cannot elongate after fertilization, and the valve is significantly reduced $[89,90]$. In cucumbers, CsFUL1 ${ }^{A}$ as a negative regulator can inhibit auxin transport and cell division to affect the FL [61]. CsFUL1 ${ }^{A}$ is a MADS-box family TF that can bind to the CArG-box to regulate cell division and expansion, and it can inhibit the expression of auxin transporters PIN-FORMED1 (PIN1) and PIN7, resulting in the decreased auxin accumulation and regulation of FL [61]. 


\subsection{Fruit Weight (FW)}

The size of the fruit is closely related to FW. In the breeding process of vegetables, people have discovered several loci that regulate FW (Table 1). FW is a quantitative trait and is controlled by numerous loci [3]. FW2.2 is the first cloned FW QTL in vegetables [91]. In Solanaceae vegetables, several genes that regulate FW have been cloned. These genes, including the $l c$ and fas loci, are, respectively, homologous with WUS and YABBY2, can regulate the CN to increase FW $[48,53,92,93]$. FW3.2, fw11.2, fw1.1, fw3.3, and Cell Size Regulator (CSR) loci, which are related to FW, have been cloned in tomatoes [94-96]. In peppers, $f w 2.1, f w 4.1$, and $f w 4.2$ have been associated with FW [97]. In Cucurbitaceae, several loci have been related to FW. In cucumbers, three QTLs (fw2.1, fw4.1, and fw6.1) have been described [10]. In melons, two genomic regions, namely, FWQM8 and FWQM11, contain the loci that regulate FW [5]. A CYP78A subfamily gene KLUH can initially control the organ size in Arabidopsis. In vegetables, several members of the CYP78A subfamily have been reported to regulate FW; these members include SIKLUH (tomato), GmCYP78A10 and GmCYP78A72 (soybean), BnaA9.CYP78A9 (rapeseed), and CaKLUH (pepper) [94,98-102]. In addition, a recent study shows that the overexpression of TF gene SHINE1 (SlSHN1) can decrease the tomato FW [102].

\section{Hormonal Regulation of Fruit Shapes}

Hormones can respond to environmental and endogenous signals throughout almost the entire life of a plant. Plant hormones directly or indirectly affect the division and expansion of fruit cells in the early stages of fruit development, to regulate fruit growth, and ultimately determine the size and shape of fruits [103-105]. There are many plant hormones in nature, including auxin, cytokinin (CK), GA, ethylene, and The abscisic acid (ABA). Several of them have been reported to affect fruit shape.

Auxin plays an important role in the development of fleshy fruits [106-108]. Liu et al. [107] measured the endogenous hormone content of fruits in different cucumber inbred lines. They found that in various developmental stages, the IAA content of the fruit is positively correlated with the fruit size and cell growth [109]. In Solanum, the LA1589 near-isogenic lines, which have elongated pear-shaped ovaries and fruits, were treated with auxin (2,4-D) before anthesis, resulting in an increased cell number and size of the ovary/fruit proximal end [110]. The auxin synthesis gene CsYUC10b is associated with fruit curvature, and its overexpression can induce the formation of straight fruits [109]. In addition, SlIAA17, an auxin transcriptional repressor of Auxin/indoleacetic acid (Aux/IAA), can lead to large fruits in tomatoes [103]. SlARF9 and BnaA9.ARF18 belongs to the Auxin response factors (ARFs) family, and they can regulate fruit size in tomatoes and Brassica rapa, respectively $[103,110]$.

In addition to auxin, other hormones can work with certain regulatory factors to regulate fruit shape [111]. CKs mainly regulate cell division in plants and there is a positive correlation between them, which is consistent with the fruit cell division activity [112-114]. The CK biosynthetic gene CYP735A can change the cell volume and biomass accumulation to affect the fruit size [115]. In cucumbers, trans-Zeatin riboside (tZR) decreases in the initial stage of fruit development and is mainly involved in the cell division process at the early stage of ovary development. The content of zeatin (ZT) increases in the early stage of fruit development after flowering, which can promote the horizontal expansion of cells in the early stage [107]. GA may regulate flowering and stimulate fruit and seed development [114]. Exogenous application of GA can induce cell enlargement and lead to parthenocarpy $[116,117]$. In cucumbers, GA can promote cell expansion during fruit development [118] and antagonize IAA in the mid-to-early stage (9-12 days after anthesis); it may inhibit fruit elongation by hindering cell division [105]. During the development of the tomato fruit, the GA accumulation is consistent with the direction of cell division and expansion in the early stage [119]. Ethylene is mostly related to fruit ripening in tomatoes [120], but recent reports have shown that it can regulate the length of the cucumber fruit. Ethylene content also affects plant development [119]. 1-aminocyclopropane-1- 
carboxylate synthase 2 (ACS2) can catalyze the biosynthesis of ethylene [119]; the ethylenedecreased cucumber mutant acs 2 shortens the FL. However, in sf1 mutants, excessive ethylene content can also lead to the same phenotype [60]. Therefore, an excessive or inadequate amount of ethylene can affect the FL. The ACS homologous gene CmACS7 is related to the round fruits of melons $[5,121]$. These results showed that the dose-dependent function of ethylene in Cucurbitaceae is relatively conserved. In a separate study on tomatoes, several Aux/IAA-like genes (DR1, DR3, DR4, and DR8) related to IAA transcript accumulation were differentially regulated by ethylene [122]. ABA is a plant growth inhibitory hormone [123], Nitsch et al. [124] pointed out that in tomatoes, the ABA-deficient mutant not/flc has a small fruit and cell shape $[123,125]$. The above research shows the possible antagonistic or synergistic effects between plant hormones, which together regulate fruit development and ultimately affect fruit shape.

Table 1. Genes involved in the fruit size regulation of vegetables.

\begin{tabular}{|c|c|c|c|c|c|}
\hline Type & Pathways & Gene Name & Species & Function in Size & Reference \\
\hline \multirow[t]{5}{*}{$\mathrm{CN}$} & CLV-WUS pathway & CsWUS, CsCLV3 & Cucumber & $\begin{array}{c}\text { CsFUL1 }^{A} \text { and CSARF14 can regulate the } \\
\text { CsWUS-CsCLV3 pathway and work together to } \\
\text { participate in the regulation mechanism of } \\
\text { cucumber CN. }\end{array}$ & [47] \\
\hline & & $\begin{array}{l}\text { SlCLV, CLV3, } \\
\text { and WUS }\end{array}$ & Tomato & $\begin{array}{l}\text { Loss-of-function mutation } S I C L V 3 \text { leads to a large } \\
\text { fruit with an increased number of locules. } \\
\text { A mutation of } C L V 3 \text { in tomatoes can increase the } \\
\text { fruit size. } \\
L C \text {, which is encoded by WUS, and FAS, which is } \\
\text { encoded by CLV3, can lead to an increased } \\
\text { locule number. }\end{array}$ & {$[48-50,53]$} \\
\hline & & CLV1 & Rapeseed & $\begin{array}{l}\text { The interruption of } C L V 1 \text { results in a } \\
\text { trilocular phenotype. }\end{array}$ & [50] \\
\hline & & SlWUS & Tomato & $\begin{array}{c}\text { Up-regulation of SlWUS can increase the } \mathrm{CN} \text { and } \\
\text { affect fruit shape. }\end{array}$ & [52] \\
\hline & MicroRNA & MIR156 & Tomato & $\begin{array}{l}\text { MIR156 overexpression alters the tomato fruit } \\
\text { locule number. }\end{array}$ & [54] \\
\hline \multirow[t]{7}{*}{ FL } & & $\begin{array}{c}\text { CmSUN2 } \\
(\text { CmSUN-14) }\end{array}$ & Melon & $\begin{array}{c}\text { CmSUN-14 belongs to the SUN family and can } \\
\text { regulate the FL. }\end{array}$ & {$[5,79]$} \\
\hline & $\begin{array}{l}\text { OFP-TRM-SUN } \\
\text { pathway }\end{array}$ & $\begin{array}{l}\text { OVATE, } \\
\text { SIOFP20, } \\
\quad \text { SUN }\end{array}$ & Tomato & $\begin{array}{l}\text { OVATE is a pear-shaped fruit regulatory gene. OFPs } \\
\text { with a conserved OVATE domain play an important } \\
\text { role in regulating fruit size. } \\
\text { OVATE and SIOFP20 interact with the TRM and } \\
\text { work together to regulate cell division and } \\
\text { organ growth. } \\
\text { SUN encodes a protein of the IQD family, which has } \\
\text { a conserved IQD and is involved in the binding of } \\
\text { CaM, which controls the FL and fruit shape. }\end{array}$ & {$[38,66,73,76]$} \\
\hline & Cell development & $\begin{array}{l}\text { CsSUN25-26-27a } \\
\text { (CsGy1G026840.1, } \\
\text { Csa1G575000) }\end{array}$ & Cucumber & $\begin{array}{l}\text { CsGy1G026840.1 and Csa1G575000 belong to the } \\
\text { SUN family and can regulate the Fl. }\end{array}$ & {$[39,78]$} \\
\hline & $\begin{array}{c}\text { Hormones and cell } \\
\text { development }\end{array}$ & & Cucumber & $\begin{array}{c}\text { In cucumbers, ACS2 can catalyze the biosynthesis of } \\
\text { ethylene, ethylene decreases mutant acs2, resulting } \\
\text { in a shortened FL; however, in sf1, the excessive } \\
\text { ethylene content of the mutant can also lead to a } \\
\text { short fruit. }\end{array}$ & [60] \\
\hline & $\begin{array}{l}\mathrm{TF} \text { and } \\
\text { Hormonal regulation }\end{array}$ & CsFUL1 & Cucumber & $\begin{array}{l}\text { CsFUL1 can inhibit the expression of auxin } \\
\text { transporters PIN1 and PIN7, resulting in the } \\
\text { decreased accumulation of auxin, which affects the } \\
\text { cucumber fruit length. }\end{array}$ & [61] \\
\hline & TF & CaOvate & Pepper & $\begin{array}{l}\text { Down-regulation of the CaOvate gene leads to an } \\
\text { oblong fruit shape of pepper. }\end{array}$ & [75] \\
\hline & & $\begin{array}{l}\text { ClSUN25-26-27a } \\
\quad(\text { Cla011257) }\end{array}$ & Watermelon & $\begin{array}{l}\text { Cla011257 acts on the ovary (pre-anthesis) to affect } \\
\text { the fruit length during the development period. }\end{array}$ & {$[86,87]$} \\
\hline \multirow[t]{2}{*}{ FW } & QTLs & $\begin{array}{l}\text { FWQM8 and } \\
\text { FWQM11 }\end{array}$ & Melon & $\begin{array}{c}F W Q M 8 \text { and } F W Q M 11 \text { are genomic regions related } \\
\text { to FW in melons. }\end{array}$ & [5] \\
\hline & & $\begin{array}{l}f w 2.1, \tilde{f w} 4.1, \text { and } \\
f w 6.1\end{array}$ & Cucumber & $\begin{array}{c}\text { In cucumbers, three QTLs (fw2.1, fw4.1, and fw6.1) } \\
\text { are associated with FW. }\end{array}$ & [10] \\
\hline
\end{tabular}


Table 1. Cont.

\begin{tabular}{|c|c|c|c|c|c|}
\hline Type & Pathways & Gene Name & Species & Function in Size & Reference \\
\hline & & $\begin{array}{l}F W 2.2, l c, \text { fas, } \\
F W 3.2, f w 11.2 \\
f w 1.1, f w 3.3 \\
\quad \text { and } C S R\end{array}$ & Tomato & $\begin{array}{c}F W 2.2 \text { is the first cloned FW QTL in vegetables. } \\
l c \text { and } f a s \text { are, respectively, homologous with WUS } \\
\text { and } Y A B B Y 2 \text {, and can regulate the CN to } \\
\text { increase FW. } \\
F W 3.2, f w 11.2, f w 1.1, f w 3.3 \text {, and CSR loci have been } \\
\text { cloned in tomatoes to increase FW. }\end{array}$ & {$[48,55,91-96]$} \\
\hline & $\begin{array}{l}\text { The CYP78A } \\
\text { subfamily }\end{array}$ & $\begin{array}{l}G m C Y P 78 A 10 \\
\text { and } \\
G m C Y P 78 A 72\end{array}$ & Soybean & $\begin{array}{c}G m C Y P 78 A 10 \text { and } G m C Y P 78 A 72 \text { genes in soybeans } \\
\text { are related to FW. }\end{array}$ & {$[88,94,99]$} \\
\hline & QTLs & $\begin{array}{c}f w 2.1, f w 4.1 \text { and } \\
f w 4.2\end{array}$ & Pepper & In peppers, $f w 2.1, f w 4.1$, and $f w 4.2$ are related to FW. & [97] \\
\hline & & CaKLUH & Pepper & CaKLUH gene in pepper is related to FW. & [100] \\
\hline & $\begin{array}{l}\text { The CYP78A } \\
\text { subfamily }\end{array}$ & BnaA9.CYP78A9 & Rapeseed & BnaA9.CYP78A9 gene in rapeseed is related to FW. & [101] \\
\hline & & SlKLUH & Tomato & $\begin{array}{l}\text { SIKLUH indirectly participates in the lipid } \\
\text { metabolism of tomato fruits to regulate FW. }\end{array}$ & [102] \\
\hline \multirow{3}{*}{$\begin{array}{l}\text { Larger } \\
\text { fruit }\end{array}$} & TF & SlSHN1 & Tomato & $\begin{array}{l}\text { TF gene SlSHN1 overexpression can decrease the } \\
\text { tomato FW. }\end{array}$ & [102] \\
\hline & $\begin{array}{l}\text { Hormonal } \\
\text { regulation }\end{array}$ & SIIAA17 & Tomato & $\begin{array}{l}\text { SlIAA17, an auxin transcriptional repressor of } \\
\text { Aux/IAA, can lead to large fruits in tomatoes. }\end{array}$ & [103] \\
\hline & $\begin{array}{l}\text { Hormonal } \\
\text { regulation } \\
\text { Hormonal } \\
\text { regulation }\end{array}$ & $\begin{array}{l}\text { SlARF9 } \\
\text { BnaA9.ARF18 }\end{array}$ & $\begin{array}{l}\text { Tomato } \\
\text { Brassica rapa }\end{array}$ & $\begin{array}{l}\text { SlARF9 and BnaA9.ARF18, which belongs to the } \\
\text { ARFs family, can regulate fruit size in tomatoes and } \\
\text { Brassica rapa, respectively. }\end{array}$ & [110] \\
\hline \multirow[t]{2}{*}{$\begin{array}{l}\text { Round } \\
\text { fruit }\end{array}$} & $\begin{array}{l}\text { Hormonal } \\
\text { regulation }\end{array}$ & CmACS7 & Melon & $\begin{array}{c}\text { The ACS homologous gene CmACS7 is related to the } \\
\text { round fruits of melons. }\end{array}$ & {$[5,121]$} \\
\hline & $\begin{array}{l}\text { Hormonal } \\
\text { regulation }\end{array}$ & not/flc & Tomato & $\begin{array}{l}\text { The ABA-deficient mutant not/flc results in a small } \\
\text { fruit and cell shape in tomatoes. }\end{array}$ & [124] \\
\hline
\end{tabular}

\section{Conclusions and Perspectives}

Global climate change and urbanization affect crop cultivation. Numerous challenges, including the reduced planting land, the presence of pest hazards, and pesticide residues, are associated with vegetable crops. Therefore, the application of molecular biology techniques is a powerful solution to these challenges. The fruit shape of vegetable crops is one of the most important agronomic traits. The research on the development pathways and regulation mechanisms of fruit shape can not only increase vegetable market value but also contribute to the economic development of the whole vegetable industry. The shape of fleshy fruit vegetables, such as tomatoes and cucumbers, directly determines the market ranks and culinary use [126]. Thus, based on the fruit shape regulatory network, people can produce new varieties of vegetables that meet the needs of different consumers. In cruciferous and other dried fruit vegetables, the fruit shape is mainly related to crop yield. The research on fruit shape can not only increase crop yields but also bring great economic value.

In this review, we summarized the domestication process and analyzed the genetic and molecular regulation mechanisms in vegetable crops (Figure 2). Given the different fruit types in various species, the fruit shape of the same gene can be diverse. In addition, we observe that fruit shape is regulated by a single factor and common influencing factors. During fruit development, hormonal changes can affect the TF functions, which lead to cell morphological variations that affect the final fruit shape. At present, a limited number of genes have been reported to regulate fruit shape. Researchers should aim to discover more key genes in the future. In addition, comprehensive studies combining multiple levels, genomics, and perspectives (plant hormones, cytology, and candidate genes) should be performed. From the initial domestication to modern molecular breeding, the fruit shape of vegetable crops has been influenced by human selection. In recent years, molecular biological methods, such as whole-genome research and resequencing technology, have provided great help for fruit shape research. At present, people mainly focus on the discovery of important trait genes. In the future, breeders may combine omics research and 
practical technology to cultivate plants with ideal fruit shapes through design breeding and use the gene-editing technology CRISPR/Cas9 for future applications.

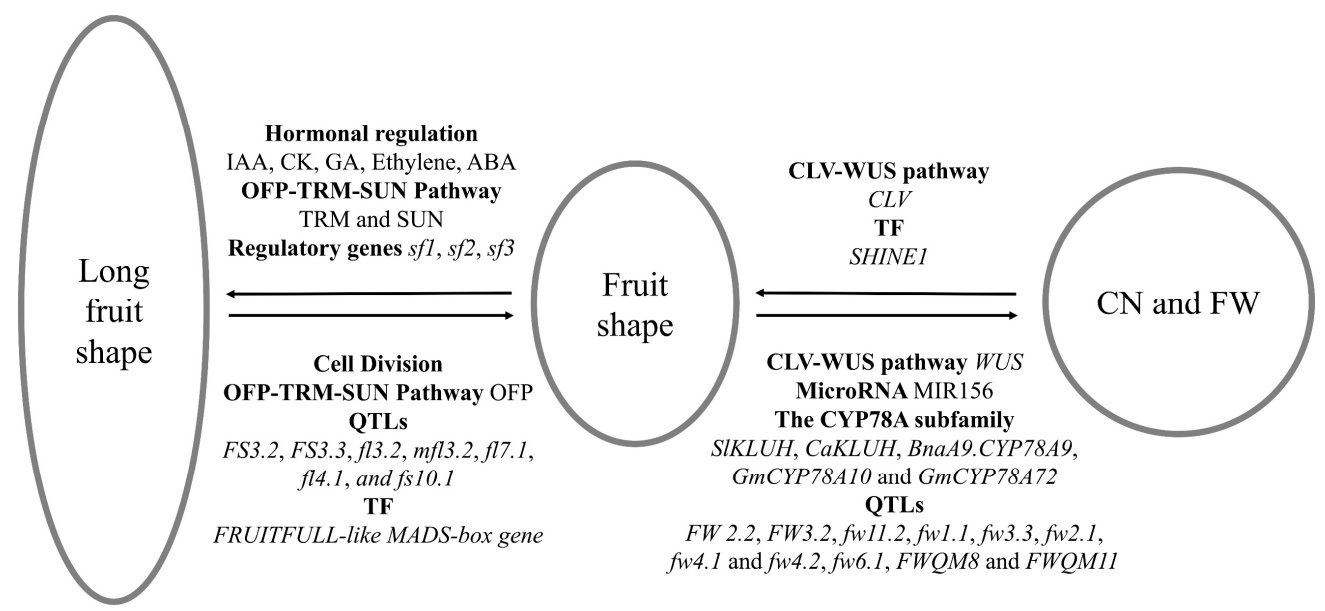

Figure 2. Fruit shape is regulated by several other signaling pathways. These regulation pathways include hormonal regulations, OFP-TRM-SUN pathway, regulatory genes, cell division, QTLs, and TF, which affect the fruit length. The TF, CLV-WUS signaling pathway, MicroRNA, the CYP78A subfamily, and QTLs affect the CN and the FW. These pathways are shown around in red.

Author Contributions: Writing-original draft preparation, C.W., N.H., J.C. and T.W.; Writingreview and editing, C.W., N.H., J.C. and T.W. All authors have read and agreed to the published version of the manuscript.

Funding: This work was supported in part by the National Key Research and Development Program of China, project number 2018YFD1000800. This research was also supported by National Natural Science Foundation of China, project number31972429, 31972407, 32011540003, and Hunan Provincial Natural Science Foundation of China, project number 2020JJ4363, 2021JJ10032.

Institutional Review Board Statement: Not applicable.

Informed Consent Statement: Not applicable.

Data Availability Statement: Not applicable.

Conflicts of Interest: The authors declare no conflict of interest.

\section{References}

1. Seymour, G.B.; Ostergaard, L.; Chapman, N.H.; Knapp, S.; Martin, C. Fruit development and ripening. Annu. Rev. Plant Biol. 2013, 64, 219-241. [CrossRef] [PubMed]

2. Van der Knaap, E.; Chakrabarti, M.; Chu, Y.H.; Clevenger, J.P.; Illa-Brenguer, E.; Huang, Z.J.; Keyhaninejad, N.; Mu, Q.; Sun, L.; Wang, Y.P.; et al. What lies beyond the eye: The molecular mechanisms regulating tomato fruit weight and shape. Front. Plant Sci. 2014, 5, 227. [CrossRef] [PubMed]

3. Paran, I.; van der Knaap, E. Genetic and molecular regulation of fruit and plant domestication traits in tomato and pepper. J. Exp. Bot. 2007, 58, 3841-3852. [CrossRef]

4. Pickersgill, B. Domestication of plants in the Americas: Insights from mendelian and molecular genetics. Ann. Bot. 2007, 5, 925-940. [CrossRef] [PubMed]

5. Monforte, A.J.; Diaz, A.I.; Cano-Delgado, A.; van der Knaap, E. The genetic basis of fruit morphology in horticultural crops: Lessons from tomato and melon. J. Exp. Bot. 2014, 65, 4625-4637. [CrossRef]

6. Gong, L.; Harry, S.P.; Michael, H.N.; Gertraud, S.; Martin, P.; Johann, V.; Tamas, L. Genetic relationships and evolution in Cucurbita pepo (pumpkin, squash, gourd) as revealed by simple sequence repeat polymorphisms. Theor. Appl. Genet. 2012, 124, 875-891. [CrossRef] [PubMed]

7. Sinnott, E.W.; Durham, G.B. Developmental history of the fruit in lines of Cucurbita pepo differing in fruit shape. Bot. Gaz. 1929, 87, 411-421. [CrossRef]

8. Macarthur, J.W.; Butler, L. Size inheritance and geometric growth processes in the tomato fruit. Genetics 1938, 23, 253-268. [CrossRef] 
9. Fanwoua, J.; de Visser, P.H.B.; Heuvelink, E.; Yin, X.; Struik, P.C.; Marcelis, L.F.M. A dynamic model of tomato fruit growth integrating cell division, cell growth and endoreduplication. Funct. Plant Biol. 2013, 40, 1098-1114. [CrossRef] [PubMed]

10. Bo, K.; Ma, Z.; Chen, J.; Weng, Y. Molecular mapping reveals structural rearrangements and quantitative trait loci underlying traits with local adaptation in semi-wild Xishuangbanna cucumber (Cucumis sativus L. var. xishuangbannanesis Qi et Yuan). Theor. Appl. Genet. 2015, 128, 25-39. [CrossRef]

11. Sinnott, E.W. A developmental analysis of inherited shape differences in cucurbit fruits. Am. Nat. 1936, 70, 245-254. [CrossRef]

12. Colle, M.; Weng, Y.Q.; Kang, Y.Y.; Ophir, R.; Sherman, A.; Grumet, R. Variation in cucumber (Cucumis sativus L.) fruit size and shape results from multiple components acting pre-anthesis and post-pollination. Planta 2017, 246, 641-658. [CrossRef] [PubMed]

13. Qu, Z.Z.; Wang, Y.H.; Zhou, J.Z.; Peng, S.Q. The relationship between fruit development and cell division and expansion in Chinese jujube. J. Hebei Agric. Univ. 1964, 1, 1-15.

14. Hu, D.L.; Richards, P.; Alexeev, A. The growth of giant pumpkins: How extreme weight influences shape. Int. J. Non-Linear Mech. 2011, 46, 637-647. [CrossRef]

15. Nakata, Y.; Taniguchi, G.; Takazaki, S.; Ode-Uda, N.; Miyahara, K.; Ohshima, Y. Comparative analysis of cells and proteins of pumpkin plants for the control of fruit size. J. Biosci. Bioeng. 2012, 114, 334-341. [CrossRef] [PubMed]

16. Sinnott, E.W. The independence of genetic factors governing size and shape. J. Hered. 1931, 22, 381-387. [CrossRef]

17. Yang, X.Y.; Wang, Y.; Jiang, W.J.; Liu, X.L.; Zhang, X.M.; Yu, H.J.; Huang, S.W.; Liu, G.Q. Characterization and expression profiling of cucumber kinesin genes during early fruit development: Revealing the roles of kinesins in exponential cell production and enlargement in cucumber fruit. J. Exp. Bot. 2013, 14, 4541-4557. [CrossRef] [PubMed]

18. Sinnott, E.W. A developmental analysis of the relation between cell size and fruit size in cucurbits. Am. J. Bot. 1939, 26, 179-189. [CrossRef]

19. Sinnott, E.W. The relation of growth to size in cucurbit fruits. Am. J. Bot. 1945, 32, 439-446. [CrossRef]

20. Sinnott, E.W. The genetic basis of organic form. Ann. N. Y. Acad. Sci. 1958, 71, 1223-1233. [CrossRef]

21. Hammami, S.; Manrique, T.; Rapoport, H.F. Cultivar-based fruit size in olive depends on different tissue and cellular processes throughout growth. Sci. Hortic. 2011, 130, 445-451. [CrossRef]

22. Bohner, J.; Bangerth, F. Cell number, cell size and hormone levels in semi-isogenic mutants of Lycopersicon pimpinellifolium differing in fruit size. Physiol. Plant 1988, 72, 316-320. [CrossRef]

23. Rosati, A.; Caporalia, S.; Hammami, S.; Moreno-Alıás, I.; Paolettia, A.; Rapaport, H. Differences in ovary size among olive (Olea europaea L.) cultivars are mainly related to cell number, not to cell size. Sci. Hortic. 2011, 130, 185-190. [CrossRef]

24. Cheng, G.W.; Breen, P.J. Cell count and size in relation to fruit size among strawberry cultivars. J. Am. Soc. Hortic. Sci. 1992, 117, 946-950. [CrossRef]

25. Yamaguchi, M.; Haji, T.; Miyake, M.; Yaegaki, H. Varietal differences in cell division and enlargement periods during peach (Prunus persica Batsch) fruit development. J. Jpn. Soc. Hortic. Sci. 2002, 71, 155-163. [CrossRef]

26. Olmstead, J.W.; Whiting, M.D.; Iezzoni, A.F. Genotypic differences in sweet cherry fruit size are primarily a function of cell number. J. Am. Soc. Hortic. Sci. 2007, 132, 697-703. [CrossRef]

27. Higashi, K.; Hosoya, K.; Ezura, H. Histological analysis of fruit development between two melon (Cucumis melo L. reticulatus) genotypes setting a different size of fruit. J. Exp. Bot. 1999, 50, 1593-1597. [CrossRef]

28. Cheniclet, C.; Rong, W.Y.; Causse, M.; Frangne, N.; Bolling, L.; Carde, J.P.; Renaudin, J.P. Cell expansion and endoreduplication show a large genetic variability in pericarp and contribute strongly to tomato fruit growth. Plant Physiol. 2005, 139, 1984-1994. [CrossRef]

29. Gillaspy, G.; Ben-David, H.; Gruissem, W. Fruits: A developmental perspective. Plant Cell 1993, 5, 1439-1451. [CrossRef]

30. Bergervoet, J.H.W.; Verhoeven, H.A.; Luun, J.W.; Gilissen, J.W.; Bino, R.J. High amounts of nuclear DNA in tomato (Lycopersicon esculentum Mill.) pericarp. Plant Sci. 1996, 116, 141-145. [CrossRef]

31. Cong, B.; Liu, J.; Tanksley, S.D. Natural alleles at a tomato fruit size quantitative trait locus differ by heterochronic regulatory mutations. Proc. Natl. Acad. Sci. USA 2002, 99, 13606-13611. [CrossRef] [PubMed]

32. Tran, D.T.; Tran, T.L.H.; Hertog, M.; Picha, D.; Nicolai, B. Quality changes of tomato during fruit development and climacteric ripening. Eur. J. Hortic. Sci. 2017, 82, 319-325. [CrossRef]

33. Tanksley, S.D. The Genetic, Developmental, and Molecular Bases of Fruit Size and Shape Variation in Tomato. Plant Cell 2004, 16, S181-S189. [CrossRef] [PubMed]

34. Fox, S.; Southam, P.; Pantin, F.; Kennaway, R.; Robinson, S.; Castorina, G. Spatiotemporal coordination of cell division and growth during organ morphogenesis. PLoS Biol. 2018, 16, e2005952. [CrossRef]

35. Harashima, H.; Schnittger, A. The integration of cell division, growth and differentiation. Curr. Opin. Plant Biol. 2010, 13, 66-74. [CrossRef]

36. Shan, H.; Cheng, J.; Zhang, R.; Yao, X.; Kong, H. Developmental mechanisms involved in the diversification of flowers. Nat. Plants 2019, 5, 917-9235. [CrossRef]

37. Brewer, M.T.; Lang, L.X.; Fujimura, K.; Dujmovic, N.; Gray, S.; van der Knaap, E. Development of a controlled vocabulary and software application to analyze fruit shape variation in tomato and other plant species. Plant Physiol. 2006, 141, 15-25. [CrossRef]

38. Rodriguez, G.R.; Munos, S.; Anderson, C.; Sim, S.C.; Michel, A.; Causse, M.; Gardener, B.B.M.; Francis, D.; van der Knaap, E. Distribution of SUN, OVATE, LC, and FAS in the tomato germplasm and the relationship to fruit shape diversity. Plant Physiol. 2011, 156, 275-285. [CrossRef] 
39. Pan, Y.; Wang, Y.; Mcgregor, C.; Liu, S.; Luan, F.S.; Gao, M.L.; Weng, Y.Q. Genetic architecture of fruit size and shape variation in cucurbits: A comparative perspective. Theor. Appl. Genet. 2020, 133, 1-21. [CrossRef]

40. Fletcher, J.C.; Brand, U.; Running, M.P.; Simon, R.; Meyerowitz, E.M. Signaling of cell fate decisions by CLAVATA3 in Arabidopsis shoot meristems. Science 1999, 283, 1911-1914. [CrossRef]

41. Brand, U.; Hobe, M.; Simon, R. Functional domains in plant shoot meristems. Bioessays 2001, 23, 134-141. [CrossRef]

42. Liljegren, S.J.; Yanofsky, M.F. Genetic control of shoot and flower meristem behavior. Curr. Opin. Cell Biol. 1996, 8, 865-869. [CrossRef]

43. Koornneef, M.; Dellaert, L.W.M.; Vanderveen, J.H. EMS-and radiation-induced mutation frequencies at individual loci in Arabidopsis thaliana (L.). Heynh. Mutat. Res. 1982, 93, 109-123. [CrossRef]

44. Clark, S.E.; Running, M.P.; Meyerowitz, E.M. CLAVATA1, a regulator of meristem and flower development in Arabidopsis. Development 1993, 119, 397-418. [CrossRef] [PubMed]

45. Kayes, J.M.; Clark, S.E. CLAVATA2, a regulator of meristem and organ development in Arabidopsis. Development 1998, 125, 3843-3851. [CrossRef]

46. Galli, M.; Gallavotti, A. Expanding the regulatory network for meristem size in plants. Trends. Genet. 2016, 32, 372-383. [CrossRef]

47. Che, G.; Gu, R.; Zhao, J.Y.; Liu, X.F.; Song, X.F.; Zi, H.L.; Cheng, Z.H.; Shen, J.J.; Wang, Z.Y.; Liu, R.Y.; et al. Gene regulatory network controlling carpel number variation in cucumber. Development 2020, 147, dev184788. [CrossRef]

48. Lippman, Z.; Tanksley, S.D. Dissecting the genetic pathway to extreme fruit size in tomato using a cross between the small-fruited wild species Lycopersicon pimpinellifolium and L-esculentum var. giant heirloom. GENETICS 2001, 158, 413-422. [CrossRef]

49. Yuste-Lisbona, F.J.; Fernandez-Lozano, A.; Pineda, B.; Bretones, S.; Ortiz-Atienza, A.; Garcia-Sogo, B.; Muller, N.A.; Angosto, T.; Capel, J.; Moreno, V.; et al. ENO regulates tomato fruit size through the floral meristem development network. Proc. Natl. Acad. Sci. USA 2020, 117, 8187-8195. [CrossRef]

50. Xu, P.; Cao, S.; Hu, K.; Wang, X.; Huang, W.; Wang, G.; Lv, Z.; Liu, Z.; Wen, J.; Yi, B.; et al. Trilocular phenotype in Brassica juncea L. resulted from interruption of CLAVATA1 gene homologue (BjMc1) transcription. Sci. Rep. 2017, 7, 3498. [CrossRef]

51. Niu, H.H.; Liu, X.F.; Tong, C.; Wang, H.; Li, S.; Lu, L.; Pan, Y.P.; Zhang, X.L.; Weng, Y.Q.; Li, Z. The wuschel-related homeobox1 gene of cucumber (cswox1) regulates reproductive organ development. J. Exp. Bot. 2018, 69, 5373-5387. [CrossRef] [PubMed]

52. Li, H.; Qi, M.F.; Sun, M.H.; Liu, Y.; Liu, Y.D.; Xu, T.; Li, Y.B.; Li, T.L. Tomato transcription factor SIWUS plays an important role in tomato flower and locule development. Front. Plant Sci. 2017, 8, 00457. [CrossRef] [PubMed]

53. Chu, Y.H.; Jang, J.C.; Huang, Z.J.; van der Knaap, E. Tomato locule number and fruit size controlled by natural alleles of $l c$ and fas. Plant Direct 2019, 3, e00142. [CrossRef] [PubMed]

54. Silva, E.M.; Correa, J.P.; Nogueira, F.T.; Correa, J.P.D.O.; Nogueira, F.T.S. Molecular control by non-coding RNAs during fruit development: From gynoecium patterning to fruit ripening. Front. Plant Sci. 2018, 9, 01760. [CrossRef]

55. Cong, B.; Barrero, L.S.; Tanksley, S.D. Regulatory change in $Y A B B Y$-like transcription factor led to evolution of extreme fruit size during tomato domestication. Nat. Genet. 2008, 40, 800-804. [CrossRef] [PubMed]

56. Weng, Y.; Colle, M.; Wang, Y.; Yang, L.; Rubinstein, M.; Sherman, A.; Ophir, R.; Grumet, R. QTL mapping in multiple populations and development stages reveals dynamic quantitative trait loci for fruit size in cucumbers of different market classes. Theor. Appl. Genet. 2015, 128, 1747-1763. [CrossRef] [PubMed]

57. Wei, Q.Z.; Fu, W.Y.; Wang, Y.Z.; Qin, X.D.; Wang, J.; Li, L.; Lou, Q.F.; Chen, J.F. Rapid identification of fruit length loci in cucumber (Cucumis sativus L.) using next-generation sequencing (NGS)-based QTL analysis. Sci. Rep. 2016, 6, 27496. [CrossRef] [PubMed]

58. Zhu, W.Y.; Huang, L.; Chen, L.; Yang, J.T.; Wu, J.N.; Qu, M.L.; Yao, D.Q.; Guo, C.L.; Lian, H.L.; He, H.L.; et al. A high-density genetic linkage map for cucumber (Cucumis sativus L.): Based on specific length amplified fragment (SLAF) sequencing and QTL analysis of fruit traits in cucumber. Front. Plant Sci. 2016, 7, 00437. [CrossRef]

59. Borovsky, Y.; Paran., I. Characterization of $f$ s10.1, a major QTL controlling fruit elongation in Capsicum. Theor. Appl. Genet. 2011, 123, 657-665. [CrossRef]

60. Xin, T.G.; Zhang, Z.; Li, S.; Zhang, S.; Li, Q.; Zhang, Z.H.; Huang, S.W.; Yang, X.Y. Genetic regulation of ethylene dosage for cucumber fruit elongation. Plant Cell 2019, 31, 1063-1076. [CrossRef]

61. Zhao, J.Y.; Jiang, L.; Che, G.; Pan, Y.P.; Li, Y.Q.; Hou, Y.; Zhao, W.S.; Zhong, Y.T.; Ding, L.; Yan, S.S.; et al. A functional allele of CsFUL1 regulates fruit length through repressing CsSUP and inhibiting auxin transport in cucumber. Plant Cell 2019, 31, 1289-1307. [CrossRef] [PubMed]

62. Wang, H.; Sun, J.; Yang, F.; Weng, Y.; Chen, P.; Du, S.; Wei, A.; Li, Y. CsKTN1 for a katanin p60 subunit is associated with the regulation of fruit elongation in cucumber (Cucumis sativus L.). Theor. Appl. Genet. 2021, 134, 2429-2441. [CrossRef] [PubMed]

63. Liu, J.; Van Eck, J.; Cong, B.; Tanksley, S.D. A new class of regulatory genes underlying the cause of pear-shaped tomato fruit. Proc. Natl. Acad. Sci. USA 2002, 99, 13302-13306. [CrossRef] [PubMed]

64. Zhou, S.; Hu, Z.; Li, F.; Tian, S.; Zhu, Z.; Li, A.; Chen, G. Overexpression of SlOFP20 affects floral organ and pollen development. Hortic. Res. 2019, 14, 125. [CrossRef] [PubMed]

65. Lazzaro, M.D.; Wu, S.; Snouffer, A.; Wang, Y.P.; van der Knaap, E. Plant organ shapes are regulated by protein interactions and associations with microtubules. Front. Plant Sci. 2018, 9, 1766. [CrossRef]

66. $\mathrm{Wu}, \mathrm{S}$. The Roles of OVATE and Other Elongation Genes in Regulating Proximal-Distal patterning of Tomato Fruit. Dissertations, Ph.D. Thesis, The Ohio State University, Columbus, OH, USA, 2015. 
67. Rodriguez, G.R.; Kim, H.J.; van der Knaap, E. Mapping of two suppressors of OVATE (sov) loci in tomato. Heredity 2013, 111, 256-264. [CrossRef]

68. Wang, S.; Chang, Y.; Guo, J.; Zeng, Q.; Ellis, B.E.; Chen, J.G. Arabidopsis ovate family proteins, a novel transcriptional repressor family, control multiple aspects of plant growth and development. PLoS ONE 2011, 8, e23896. [CrossRef]

69. Wang, S.; Chang, Y.; Guo, J.; Chen, J.G. Arabidopsis Ovate Family Protein 1 is a transcriptional repressor that suppresses cell elongation. Plant J. 2007, 50, 858-872. [CrossRef]

70. Hackbusch, J.; Richter, K.; Muller, J.; Salamini, F.; Uhrig, J.F. A central role of Arabidopsis thaliana ovate family proteins in networking and subcellular localization of 3-aa loop extension homeodomain proteins. Proc. Natl. Acad. Sci. USA 2005, 102, 4908-4912. [CrossRef]

71. Ma, J.; Li, C.C.; Zong, M.; Qiu, Y.H.; Liu, Y.M.; Huang, Y.T.; Xie, Y.L.; Zhang, H.J.; Wang, J.S. CmFSI8/CmOFP13 encoding an OVATE family protein controls fruit shape in melon. J. Exp. Bot. 2021, erab510. [CrossRef]

72. Snouffer, A.; Kraus, C.; van der Knaap, E. The shape of things to come: Ovate family proteins regulate plant organ shape. Curr. Opin. Plant Biol. 2020, 53, 98-105. [CrossRef] [PubMed]

73. Wu, S.; Zhang, B.Y.; Keyhaninejad, N.; Rodriguez, G.R.; Kim, H.J.; Chakrabarti, M.; Illa-Berenguer, E.; Taitano, N.K.; Gonzalo, M.J.; Buell, C.R.; et al. A common genetic mechanism underlies morphological diversity in fruits and other plant organs. Nat. Commun. 2018, 9, 4734. [CrossRef] [PubMed]

74. Hamant, O.; Heisler, M.G.; Jonsson, H.; Krupinski, P.; Uyttewaal, M.; Bokov, P.; Corson, F.; Sahlin, P.; Boudaoud, A.; Meyerowitz, E.M.; et al. Developmental patterning by mechanical signals in Arabidopsis. Science 2008, 322, 1650-1655. [CrossRef] [PubMed]

75. Tsaballa, A.; Pasentsis, K.; Darzentas, N.; Tsaftaris, A.S. Multiple evidence for the role of an Ovate-like gene in determining fruit shape in pepper. BMC Plant Biol. 2011, 11, 46. [CrossRef] [PubMed]

76. Wu, S.; Xiao, H.; Cabrera, A.; Meulia, T.; van der Knaap, E. SUN regulates vegetative and reproductive organ shape by changing cell division patterns. Plant Physiol. 2011, 157, 1175-1186. [CrossRef]

77. Wu, S.; Clevenger, J.P.; Sun, L.; Visa, S.; Kamiya, Y.; Jikumaru, Y.; Blakeslee, J.; van der Knaap, E. The control of tomato fruit elongation orchestrated by sun, ovate and $f_{s} 8.1$ in a wild relative of tomato. Plant Sci. 2015, 238, 95-104. [CrossRef]

78. Pan, Y.; Liang, X.; Gao, M.; Liu, H.; Meng, H.; Weng, Y.; Cheng, Z. Round fruit shape in WI7239 cucumber is controlled by two interacting quantitative trait loci with one putatively encoding a tomato SUN homolog. Theor. Appl. Genet. 2017, 130, 573-586. [CrossRef]

79. Perpiñá, G.; Esteras, C.; Gibon, Y.; Monforte, A.J.; Picó, B. A new genomic library of melon introgression lines in a cantaloupe genetic background for dissecting desirable agronomical traits. BMC Plant Biol. 2016, 16, 154. [CrossRef]

80. Rhoads, A.R.; Friedberg, F. Sequence motifs for calmodulin recognition. FASEB J. 1997, 11, 331-340. [CrossRef]

81. Abel, S.; Savchenko, T.; Levy, M. Genome-wide comparative analysis of the IQD gene families in Arabidopsis thaliana and Oryza sativa. BMC Evol. Biol. 2005, 5, 72. [CrossRef]

82. Abel, S.; Burstenbinder, K.; Muller, J. The emerging function of IQD proteins as scaffolds in cellular signaling and trafficking. Plant Signal. Behav. 2013, 8, e24369. [CrossRef] [PubMed]

83. Clevenge, J.P.; Houten, J.V.; Blackwood, M.; Rubén Rodrígue, G.; Jikumar, Y.; Kamiya, Y.; Kusano, M.; Saito, K.; Visa, S.; van der Knaap, E. Network analyses reveal shifts in transcript profiles and metabolites that accompany the expression of SUN and an elongated tomato fruit. Plant Physiol. 2015, 168, 1164-1178. [CrossRef] [PubMed]

84. Jin, B.; Kim, J.; Jung, J.; Kim, D.; Park, Y. Characterization of IQ domain gene homologs as common candidate genes for elongated fruit shape in cucurbits. Hortic. Sci. Technol. 2018, 36, 85-97. [CrossRef]

85. Yalovsky, S. Protein lipid modifications and the regulation of ROP GTPase function. J. Exp. Bot. 2015, 66, 1617-1624. [CrossRef] [PubMed]

86. Dou, J.L.; Zhao, S.J.; Lu, X.Q.; He, N.; Zhang, L.; Ali, A.; Kuang, H.H.; Liu, W.G. Genetic mapping reveals a candidate gene (ClFS1) for fruit shape in watermelon (Citrullus lanatus L.). Theor. Appl. Genet. 2018, 131, 947-958. [CrossRef] [PubMed]

87. Legendre, R.; Kuzy, J.; McGregor, C. Markers for selection of three alleles of ClSUN25-26-27a (Cla011257) associated with fruit shape in watermelon. Mol. Breed. 2020, 40, 19. [CrossRef]

88. Wang, X.; Li, Y.; Zhang, H.; Sun, G.; Zhang, W.; Qiu, L. Evolution and association analysis of GmCYP78A10 gene with seed size/weight and pod number in soybean. Mol. Biol. Rep. 2015, 42, 489-496. [CrossRef]

89. Ferrandiz, C.; Liljegren, S.J.; Yanofsky, M.F. Negative regulation of the SHATTERPROOF genes by FRUITFULL during Arabidopsis fruit development. Science 2000, 289, 436-438. [CrossRef]

90. Langowski, L.; Stacey, N.; Ostergaard, L. Diversification of fruit shape in the Brassicaceae family. Plant Reprod. 2016, 29, 149-163. [CrossRef] [PubMed]

91. Frary, A.; Nesbitt, T.C.; Grandillo, S.; van der Knaap, E.; Cong, B.; Liu, J.; Meller, J.; Elber, R.; Alpert, K.B.; Tanksley, S.D. Fw2.2: A quantitative trait locus key to the evolution of tomato fruit size. Science 2000, 289, 85-88. [CrossRef]

92. Barrero, L.S.; Cong, B.; Wu, F.; Tanksley, S.D. Developmental characterization of the fasciated locus and mapping of Arabidopsis candidate genes involved in the control of floral meristem size and carpel number in tomato. Genome 2006, 49, 991-1006. [CrossRef] [PubMed]

93. Munos, S.; Ranc, N.; Botton, E.; Berard, A.; Rolland, S.; Duffe, P.; Carretero, Y.; Le Paslier, M.C.; Delalande, C.; Bouzayen, M.; et al. Increase in tomato locule number is controlled by two single-nucleotide polymorphisms located near WUSCHEL. Plant Physiol. 2011, 156, 2244-2254. [CrossRef] [PubMed] 
94. Chakrabarti, M.; Zhang, N.; Sauvage, C.; Muños, S.; Blanca, J.; Cañizares, J.; Diez, M.J.; Schneider, R.; Mazourek, M.; McClead, J.; et al. A cytochrome P450 regulates a domestication trait in cultivated tomato. Proc. Natl. Acad. Sci. USA 2013, 110, 17125-17130. [CrossRef] [PubMed]

95. Illa-Berenguer, E.; Van Houten, J.; Huang, Z.; van der Knaap, E. Rapid and reliable identification of tomato fruit weight and locule number loci by QTL-seq. Theor. Appl. Genet. 2015, 128, 1329-1342. [CrossRef]

96. Mu, Q.; Huang, Z.; Chakrabarti, M.; Illa-Berenguer, E.; Liu, X.; Wang, Y.; Ramos, A.; van der Knaap, E. Fruit weight is controlled by Cell Size Regulator encoding a novel protein that is expressed in maturing tomato fruits. PLoS Genet. 2017, 13, e1006930. [CrossRef]

97. Ben Chaim, A.; Borovsky, Y.; Rao, G.U.; Gur, A.; Zamir, D.; Paran, I. Comparative QTL mapping of fruit size and shape in tomato and pepper. Isr. J. Plant Sci. 2006, 54, 191-203. [CrossRef]

98. Ma, W.; Kong, Q.; Arondel, V.; Kilaru, A.; Bates, P.D.; Thrower, N.A.; Benning, C.; Ohlrogge, J.B. Wrinkled1, a ubiquitous regulator in oil accumulating tissues from Arabidopsis embryos to oil palm mesocarp. PLoS ONE 2013, 8, e68887. [CrossRef]

99. Zhao, B.; Dai, A.; Wei, H.; Yang, S.; Wang, B.; Jiang, N.; Feng, X. Arabidopsis KLU homologue GmCYP78A72 regulates seed size in soybean. Plant Mol. Biol. 2016, 90, 33-47. [CrossRef]

100. Zhao, X.; Muhammadc, N.; Zhao, Z.X.; Yin, K.L.; Liu, Z.G.; Wang, L.X.; Luo, Z.; Wang, L.H.; Liu, M.J. Molecular regulation of fruit size in horticultural plants. Sci. Hortic. 2021, 288, 110353. [CrossRef]

101. Wang, L.; Song, J.; Guo, C.; Wang, B.; Guan, Z.; Yang, P.; Chen, X.; Zhang, Q.; King, G.J.; Wang, J.; et al. A CACTA-like transposable element in the upstream region of BnaA9.CYP78A9 acts as an enhancer to increase silique length and seed weight in rapeseed. Plant J. 2019, 98, 524-539. [CrossRef]

102. Li, Q.; Chakrabarti, M.; Taitano, N.K.; Okazaki, Y.; Saito, K.; Al-Abdallat, A.M.; van der Knaap, E. Differential expression of SIKLUH controlling fruit and seed weight is associated with changes in lipid metabolism and photosynthesis-related genes. J. Exp. Bot. 2021, 72, 1225-1244. [CrossRef] [PubMed]

103. Su, L.; Bassa, C.; Audran, C.; Mila, I.; Cheniclet, C.; Chevalier, C.; Bouzayen, M.; Roustan, J.P.; Chervin, C. The Auxin SlIAA17 transcriptional repressor controls fruit size via the regulation of endoreduplication-related cell expansion. Plant Cell Physiol. 2014, 55, 1969-1976. [CrossRef] [PubMed]

104. Kumar, R.; Tyagi, A.K.; Sharma, A.K. Genome-wide analysis of auxin response factor (ARF) gene family from tomato and analysis of their role in flower and fruit development. Mol. Genet. Genom. 2011, 285, 245-260. [CrossRef] [PubMed]

105. Devoghalaere, F.; Doucen, T.; Guitton, B.; Keeling, J.; Payne, W.; Ling, T.J.; Ross, J.J.; Hallett, I.C.; Gunaseelan, K.; Dayatilake, G.; et al. A genomics approach to understanding the role of auxin in apple (Malus x domestica) fruit size control. BMC Plant Biol. 2012, 12, 7. [CrossRef] [PubMed]

106. Pattison, R.; Csukasi, F.; Catalá, C. Mechanisms regulating auxin action during fruit development. Physiol. Plant. 2014, 151, 62-72. [CrossRef] [PubMed]

107. Liu, X.; Pan, Y.; Liu, C.; Ding, Y.; Wang, X.; Cheng, Z.; Meng, H. Cucumber fruit size and shape variations explored from the aspects of morphology, histology, and endogenous hormones. Plants 2020, 9, 772. [CrossRef] [PubMed]

108. Wang, Y.; Clevenger, J.P.; Illa-Berenguer, E.; Meulia, T.; van der Knaap, E.; Sun, L. A Comparison of sun, ovate, fs8.1 and Auxin application on tomato fruit shape and gene expression. Plant Cell Physiol. 2019, 60, 1067-1081. [CrossRef]

109. Li, S.; Wang, C.; Zhou, X.; Liu, D.; Liu, C.; Luan, J.; Qin, Z.; Xin, M. The curvature of cucumber fruits is associated with spatial variation in auxin accumulation and expression of a YUCCA biosynthesis gene. Hortic. Res. 2020, 7, 135. [CrossRef]

110. Liu, J.; Hua, W.; Hu, Z.; Yang, H.; Zhang, L.; Li, R.; Deng, L.; Sun, X.; Wang, X.; Wang, H. Natural variation in ARF18 gene simultaneously affects seed weight and silique length in polyploid rapeseed. Proc. Natl. Acad. Sci. USA 2015, 112, E5123-E5132. [CrossRef]

111. Pattison, R.J.; Catala, C. Evaluating auxin distribution in tomato (Solanum lycopersicum) through an analysis of the PIN and AUX/LAX gene families. Plant J. 2012, 70, 585-598. [CrossRef]

112. Hwang, I.; Sheen, J.; Muller, B. Cytokinin signaling networks. Annu. Rev. Plant Biol. 2012, 63, 353-380. [CrossRef] [PubMed]

113. Bohner, J.; Bangerth, F. Effects of fruit set sequence and defoliation on cell number, cell size and hormone levels of tomato fruits (Lycopersiconesculentum Mill.) within a truss. Plant Growth Regul. 1988, 7, 141-155.

114. Pang, Y.; Zang, X.Y.; Pang, F.T.; Zhou, T.H.; Tian, F.Z. Changes of CTK and few nitrogen index during development of flower and fruit in Zhanhua jujube. J. North China Agric. 2017, 5, 101-104.

115. Nardozza, S.; Cooney, J.; Boldingh, H.L.; Hewitt, K.G.; Trower, T.; Jones, D.; Thrimawithana, A.H.; Allan, A.C.; Richardson, A.C. Phytohormone and transcriptomic analysis reveals endogenous cytokinins affect kiwifruit growth under restricted carbon supply. Metabolites 2020, 10, 23. [CrossRef] [PubMed]

116. Rebers, M.; Kaneta, T.; Kawaide, H.; Yamaguchi, S.; Yang, Y.Y.; Imai, R.; Sekimoto, H.; Kamiya, Y. Regulation of gibberellin biosynthesis genes during flower and early fruit development of tomato. Plant J. 1999, 17, 241-250. [CrossRef] [PubMed]

117. Fos, M.; Nuez, F.; Garc'1a-Mart'inez, J.L. The pat-2 gene which induces natural parthenocarpy alters the gibberellin content in unpollinated tomato ovaries. Plant Physiol. 2000, 122, 471-479. [CrossRef] [PubMed]

118. Serrani, J.C.; Fos, M.; Atarés, A.; Garcia-Martinez, J.L. Effect of gibberellin and auxin on parthenocarpic fruit growth induction in the cv micro-tom of tomato. J. Plant Growth Regul. 2007, 26, 211-221. [CrossRef]

119. Srivastava, A.; Handa, A.K. Hormonal Regulation of Tomato Fruit Development: A Molecular Perspective. J. Plant Growth Regul. 2005, 24, 67-82. [CrossRef] 
120. Vandenbussche, F.; Vaseva, I.; Vissenberg, K.; Van Der Straeten, D. Ethylene in vegetative development: A tale with a riddle. New Phytol. 2012, 194, 895-909. [CrossRef]

121. Boualem, A.; Troadec, C.; Camps, C.; Lemhemdi, A.; Morin, H.; Sari, M.A.; Fraenkel-Zagouri, R.; Kovalski, I.; Dogimont, C.; Perl-Treves, R.; et al. A cucurbit androecy gene revealed how unisexual flowers develop and dioecy emerges. Science 2015, 350, 688-691. [CrossRef]

122. Jones, B.; Frasse, P.; Olmos, E.; Zegzouti, H.; Li, Z.G.; Latché, A.; Pech, J.C.; Bouzayen, M. Down-regulation of DR12 an auxinresponse-factor homolog in the tomato results in a pleiotropic phenotype including dark green and blotchy ripening fruit. Plant $J$. 2002, 32, 603-613. [CrossRef] [PubMed]

123. Cutler, S.R.; Rodriguez, P.L.; Finkelstein, R.R.; Abrams, S.R. Abscisic acid: Emergence of a core signaling network. Annu. Rev. Plant Biol. 2010, 61, 651-679. [CrossRef] [PubMed]

124. Nitsch, L.; Kohlen, W.; Oplaat, C.; Charnikhova, T.; Cristescu, S.; Michieli, P.; Wolters Arts, M.; Bouwmeester, H.; Mariani, C.; Vriezen, W.H.; et al. ABA-deficiency results in reduced plant and fruit size in tomato. J. Plant Physiol. 2012, 169, 878-883. [CrossRef] [PubMed]

125. Liao, X.; Li, M.; Liu, B.; Yan, M.; Yu, X.; Zi, H.; Liu, R.; Yamamuro, C. Interlinked regulatory loops of ABA catabolism and biosynthesis coordinate fruit growth and ripening in woodland strawberry. Proc. Natl. Acad. Sci. USA 2018, 115, E11542-E11550. [CrossRef] [PubMed]

126. Van der Knaap, E.; Østergaard, L. Shaping a fruit: Developmental pathways that impact growth patterns. Semin. Cell Dev. Biol. 2018, 79, 27-36. [CrossRef] [PubMed] 